\title{
Spontaneous Formation of $>90 \%$ Optically Transmissive, Electrochemically Active CoP Films for Photoelectrochemical Hydrogen Evolution
}

Paul A. Kempler ${ }^{1}$, Harold J. Fu ${ }^{1}$, Zachary P. Ifkovits, ${ }^{1}$ Kimberly M. Papadantonakis ${ }^{1}$, Nathan S. Lewis ${ }^{1,2 *}$

${ }^{1}$ Division of Chemistry and Chemical Engineering, California Institute of Technology, Pasadena, CA 91125

${ }^{2}$ Beckman Institute, California Institute of Technology, Pasadena, CA 91125

*Corresponding Author: nslewis@caltech.edu

\section{Detailed Experimental Section:}

Materials: All chemicals were commercially available and used as received. Cobalt(II) chloride hexahydrate $\left(\mathrm{CoCl}_{2},>99.9 \%\right)$ and gallium-indium eutectic (GaIn, 99.99\%, metals basis) were obtained from Alfa Aesar, whereas sodium hypophosphite monohydrate $\left(\mathrm{NaPO}_{2} \mathrm{H}_{2}\right)$, boric acid $\left(\mathrm{H}_{3} \mathrm{BO}_{3},>99.5 \%\right)$, concentrated ammonium hydroxide $\left(\mathrm{NH}_{4} \mathrm{OH}\right.$, ACS reagent 28\%-30\%), potassium hydroxide $(\mathrm{KOH}, 99.99 \%)$, and TraceCERT ${ }^{\circledR}$ standards for phosphorus (P 1000 $\mathrm{mg} / \mathrm{mL}$ ) and cobalt (Co $10 \mathrm{mg} / \mathrm{mL}$ ) were obtained from Sigma-Aldrich. Hydrochloric acid (HCl, ACS grade 36.5-38\%) was obtained from Millipore. Buffered oxide etchant (6:1 (v/v) 40\% $\mathrm{NH}_{4} \mathrm{~F}$ to $\left.49 \% \mathrm{HF}\right)$ was obtained from Transene Inc. Sodium chloride $(\mathrm{NaCl}, 99 \%)$ and hydrogen peroxide $\left(\mathrm{H}_{2} \mathrm{O}_{2}\right.$, ACS grade 30\%) were obtained from Macron Chemicals. TraceMetal grade sulfuric acid $\left(\mathrm{H}_{2} \mathrm{SO}_{4}\right)$ was obtained from Fisher Scientific and diluted to $0.50 \mathrm{M}$ with water having a resistivity of $18.2 \mathrm{M} \Omega \cdot \mathrm{cm}$, obtained from a Millipore deionized (DI) water system. Ptype Si wafers with a resistivity of 10-20 $\Omega$-cm and n-type Si wafers with a resistivity of $<0.005$ $\Omega$-cm, both with diameters of $100 \mathrm{~mm}$, thicknesses of $525 \mu \mathrm{m}$, and $<100>$ orientation, were obtained from Addison Engineering. Fluorine-doped tin oxide (FTO, NSG TEC ${ }^{\mathrm{TM}}$ 15) with 
dimensions of $25 \times 100 \times 2 \mathrm{~mm}$ and a sheet resistance of $14 \Omega / \square$ was obtained from Pilkington. PH-900 PDS diffusion dopant source wafers were purchased from Saint-Gobain.

Metallization and Doping: Silicon was cleaned via the Radio Corporation of America (RCA) standard cleaning procedure. Silicon chips cleaved from 4" diameter wafers were soaked in a 5:1:1 (vol) $\mathrm{H}_{2} \mathrm{O}: \mathrm{NH}_{4} \mathrm{OH}: \mathrm{H}_{2} \mathrm{O}_{2}$ solution at $70-75{ }^{\circ} \mathrm{C}$ for 15 min to remove organics and particles, then dipped in buffered oxide etchant for $10 \mathrm{~s}$, and soaked in a $6: 1: 1 \mathrm{H}_{2} \mathrm{O}: \mathrm{HCl}: \mathrm{H}_{2} \mathrm{O}_{2}$ solution at $65-70{ }^{\circ} \mathrm{C}$ for $10 \mathrm{~min}$ to remove metal ion impurities. Samples were dipped in buffered oxide etchant to remove surficial $\mathrm{SiO}_{2}$ immediately prior to either metallization or doping. $\mathrm{N}^{+}$doping of silicon chips was performed in a quartz tube under 10 liters per minute $\mathrm{N}_{2}$ flow at $850^{\circ} \mathrm{C}$ with two PH-900 PDS wafers serving as the P source. Residual dopant glass on the surface of the silicon chips was removed via a 2 min soak in buffered oxide etchant. Metallization occurred in an AJA high-vacuum magnetron sputtering unit under a constant flow of $\mathrm{Ar}$ at 20 standard cubic centimeters per minute, with the chamber pressure maintained at $5 \mathrm{mtorr}$. Ti was deposited via radio-frequency (RF) sputtering at $130 \mathrm{~W}$ for $90 \mathrm{~s}$ whereas Co was deposited via RF sputtering for $90 \mathrm{~s}$ at $150 \mathrm{~W}$.

Fabrication of Electrodes: Silicon electrodes were prepared from individual 5-20 $\mathrm{mm}^{2}$ chips of metallized $\mathrm{n}^{+}-\mathrm{Si}$ and $\mathrm{n}^{+} \mathrm{p}-\mathrm{Si}$ samples. Ohmic contacts were formed via scratching In-Ga into the backside of the chips. FTO electrodes were prepared from $20-30 \mathrm{~mm}^{2}$ chips of metallized FTO samples. An adhesive Ag paint having a grain size $<1.0 \mu \mathrm{m}$ (PELCO, Ted Pella) was used to affix the chips to a $\mathrm{Cu}-\mathrm{Sn}$ wire that had been fed through $6 \mathrm{~mm}$ outer diameter borosilicate glass tubing that was $1 \mathrm{~mm}$ thick. Photoactive $\mathrm{n}^{+} \mathrm{p}$-Si chips and FTO samples were sealed onto the end of the glass tubing using an opaque, insulating epoxy (Hysol 9460), whereas $\mathrm{n}^{+}-\mathrm{Si}$ samples used 
for ellipsometry were fixed to the tubing using clear nail polish, which facilitated removal of the samples from the electrode assembly prior to ellipsometric measurements.

(Photo)electrochemical Measurements: (Photo)electrochemical depositions and hydrogenevolution testing were performed using a Biologic SP-200 potentiostat. Single-compartment glass cells were used for both deposition and testing, with a saturated calomel electrode serving as the reference electrode and a high-purity graphite rod (Alfa Aesar) serving as the counter electrode. The illumination source for depositions was a Thorlabs narrow-band light-emitting diode with a nominal wavelength of $625 \mathrm{~nm}$. The performance of photocathodes for photoelectrochemical hydrogen evolution was measured in $\mathrm{H}_{2}$-purged $0.50 \mathrm{M} \mathrm{H}_{2} \mathrm{SO}_{4}(\mathrm{aq})$ under $100 \mathrm{~mW} \mathrm{~cm}{ }^{-2}$ of simulated AM1.5 illumination produced by a filtered $\mathrm{Hg}$ (Xe) lamp powered at 290 W. In-situ transmittance spectra of CoP were recorded using a Biologic VMP3 Multichannel potentiostat connected to a calibrated reference diode (Thorlabs FDS100-CAL) and lock-in amplifier. The illumination source was a Xe lamp powered at $150 \mathrm{~W}$. The illumination was passed through a monochromator controlled via LabView, and chopped at 10-15 Hz. Light was passed through catalyst films deposited on FTO and collected at the reference diode during electrochemical characterization. Transmittance data were calculated relative to the signal collected through a bare FTO electrode in the cell.

Activation of Electrodeposited CoP: As deposited CoP films were activated via exposure to 10 $\mathrm{mL} 0.50 \mathrm{M} \mathrm{H}_{2} \mathrm{SO}_{4}(\mathrm{aq})$ at room temperature under a standard atmosphere. after a specified exposure time. Samples were rinsed with deionized water and dried under a $\mathrm{N}_{2}(\mathrm{~g})$ stream to prevent further etching of the film.

Physical characterization: Scanning-electron micrographs (SEMs) were recorded with a FEI Nova NanoSEM 450 at an accelerating voltage of $10.00 \mathrm{kV}$, with a working distance of $5 \mathrm{~mm}$, 
and recorded via an in-lens secondary-electron detector. Cross sections were obtained by cleaving the $\mathrm{n}^{+}-\mathrm{Si}$ substrate along the $<100>$ plane. Atomic-force micrographs were recorded with a Bruker Dimension Icon using Peak Force Tapping mode. The Peak Force amplitude and frequency were set to $150 \mathrm{~nm}$ and $2 \mathrm{kHz}$, respectively. For each tapping cycle, a force versus distance curve was recorded by the instrument and a feedback signal was based on the maximum force between the probe and sample. ScanAsyst-Air probes (Bruker) had a nominal tip radius of $2 \mathrm{~nm}$.

Optical constants were investigated by use of a variable-angle spectroscopic ellipsometer with a rotating analyzer (J.A. Woolam Co., Inc.). Measurements were recorded at an angle of incidence of $70^{\circ}$ in $5 \mathrm{~nm}$ increments in wavelength over a range from 300 to $1100 \mathrm{~nm}$. A model consisting of a $\mathrm{Si}$ substrate, a $1 \mathrm{~nm} \mathrm{Ti}$ interlayer, and a user-defined "effective medium approximation", EMA, layer composed of CoP and void regions was used to analyze the optical properties of the films as a function of thickness and time immersed in $0.50 \mathrm{M} \mathrm{H}_{2} \mathrm{SO}_{4}(\mathrm{aq})$. A fixed set of optical constants was assumed for the metal fraction of the film, based on the average set of $n$ and $k$ values measured for $\mathrm{CoP}$ films characterized prior to exposure to $0.50 \mathrm{M}$ $\mathrm{H}_{2} \mathrm{SO}_{4}$ (aq). Only the void fraction and depolarization factor were allowed to vary within an individual set of measurements, whereas the thickness was selected as a constant value that produced the lowest mean-square error (MSE) value across the individual measurements. Allowing for a graded index of refraction within the EMA layer improved the fit (lowered the MSE) but could not be independently verified and was therefore excluded from the model. Allowing the optical properties of the metal fractions to vary would have similarly improved the fit by providing additional degrees of freedom, but no independent measurements could be performed on continuous CoP films after exposure to acid. Hence, in the absence of direct 
physical data, the optical properties were assumed to be best approximated by those of the "asdeposited" film composition.

Measurement of corrosion products: Dissolved $\mathrm{Co}$ and $\mathrm{P}$ in $0.50 \mathrm{M} \mathrm{H}_{2} \mathrm{SO}_{4}$ (aq) were quantified via inductively coupled plasma mass spectrometry, ICP-MS, as a function of time spent in acid under galvanostatic control at $-10 \mathrm{~mA} \mathrm{~cm}^{-2}$. The volume of the electrolyte was $50 \mathrm{~mL}$. Samples were recorded by withdrawing $0.500 \mathrm{~mL}$ of electrolyte at specified time intervals, which were diluted to a volume of $5.00 \mathrm{~mL}$ with deionized water for analysis. To avoid interference from sulfur in the electrolyte, phosphorus was quantified in mass-shift mode by forming a $\mathrm{PO}^{+}$species detected at a mass to charge ratio of 47 . Concentrations were calculated by comparing ion counts to calibration curves prepared from certified standard solutions.
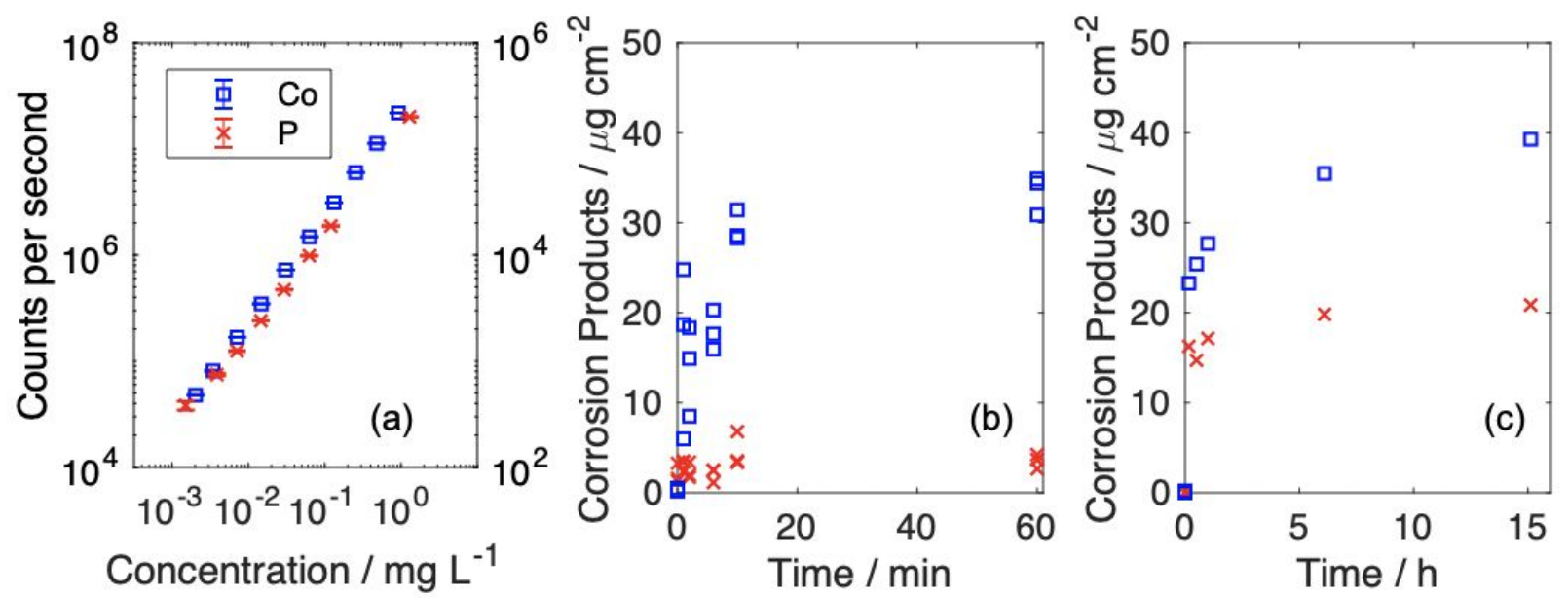

Figure S1: (a) Calibration of ICP-MS method from TraceCERT® standard solutions for P and Co prepared by serial dilution. (b,c) Corrosion products detected by ICP-MS for $\mathrm{n}^{+}-$ $\mathrm{Si}(100) / \mathrm{Ti} / \mathrm{CoP}\left(800 \mathrm{mC} \mathrm{cm}^{-2}\right)$ electrodes held at $-10 \mathrm{~mA} \mathrm{~cm}{ }^{-2}$ in $\mathrm{H}_{2}$ purged $0.50 \mathrm{M} \mathrm{H}_{2} \mathrm{SO}_{4}$. 


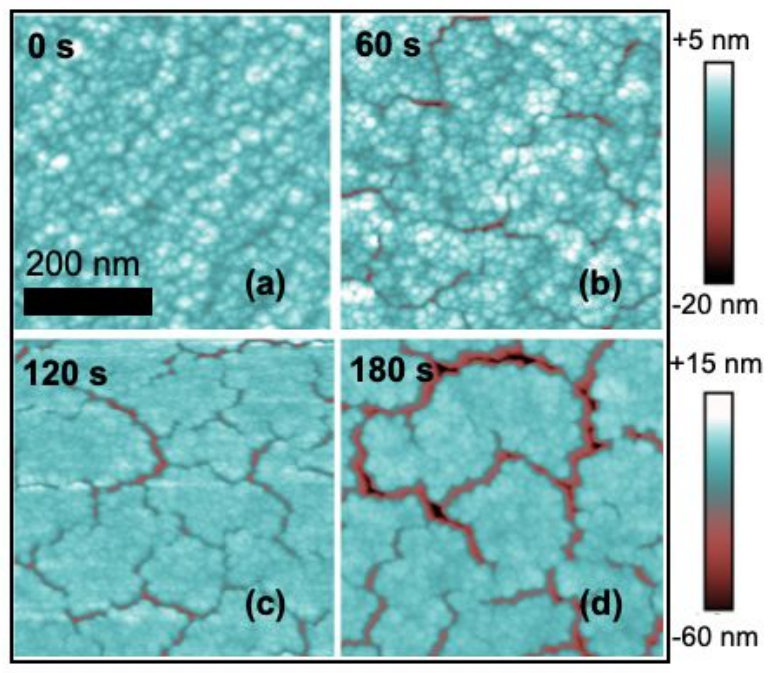

Figure S2: AFM image series of a single $\mathrm{n}^{+}-\mathrm{Si}(100) / \mathrm{Ti} / \mathrm{CoP}\left(800 \mathrm{mC} \mathrm{cm}^{-2}\right)$ surface after progressive exposure times to $0.50 \mathrm{M} \mathrm{H}_{2} \mathrm{SO}_{4}(\mathrm{aq})$. The image was recorded in tapping mode with a Si tip having a nominal radius of $2 \mathrm{~nm}$.
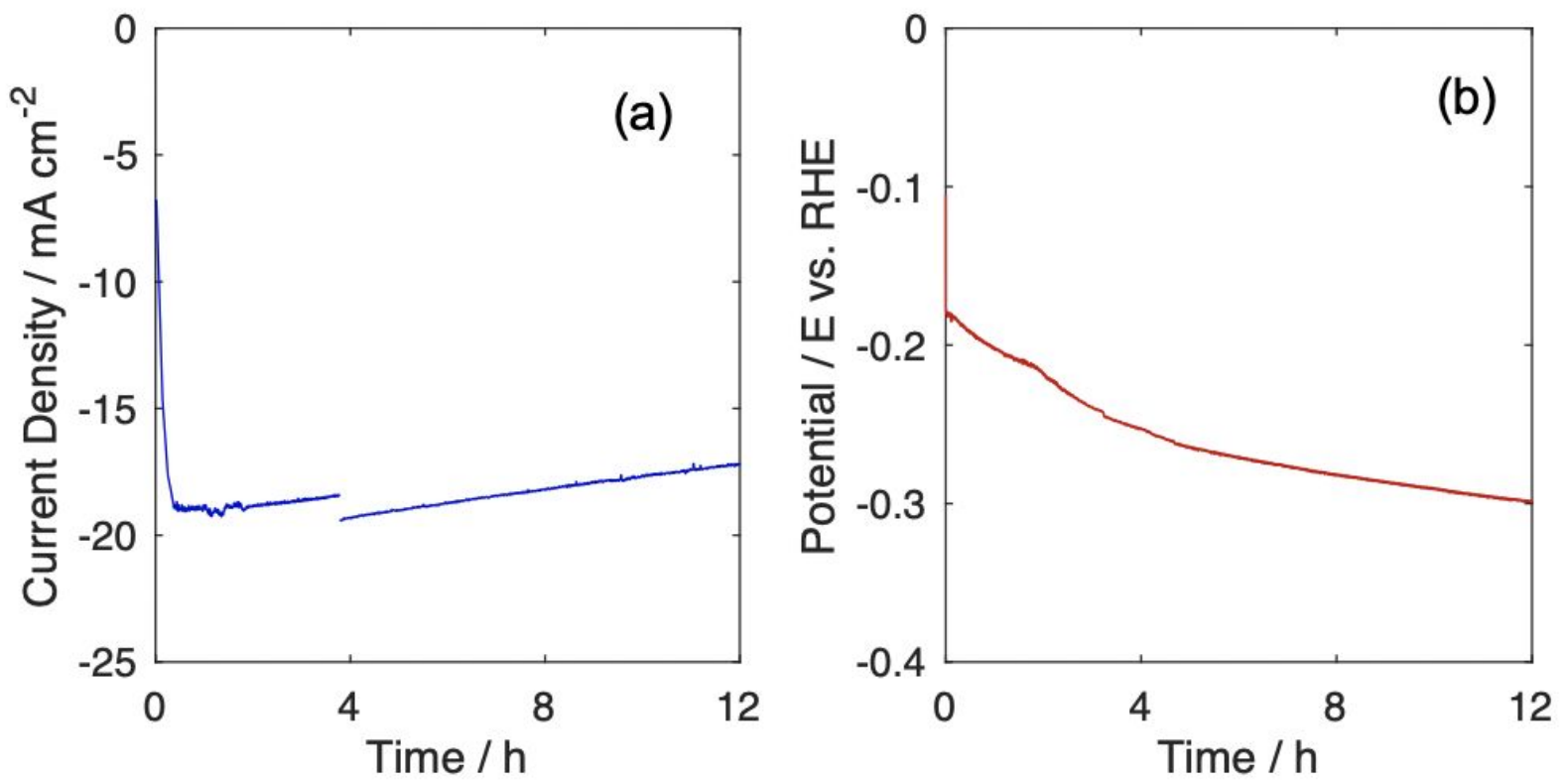

Figure S3: (a) Chronoamperogram at $0 \mathrm{~V}$ vs the reversible hydrogen electrode (RHE) of an $\mathrm{n}^{+} \mathrm{p}$ $\mathrm{Si}(100) / \mathrm{Ti} / \mathrm{CoP}\left(400 \mathrm{mC} \mathrm{cm}^{-2}\right)$ photocathode under simulated $100 \mathrm{~mW} \mathrm{~cm}{ }^{-2} \mathrm{AM} 1.5$ illumination in $\mathrm{H}_{2}(\mathrm{~g})$-purged $0.50 \mathrm{M} \mathrm{H}_{2} \mathrm{SO}_{4}(\mathrm{aq})$. (b) Chronopotentiogram at $-10 \mathrm{~mA} \mathrm{~cm}{ }^{-2}$ of an $\mathrm{n}^{+}-$ $\mathrm{Si}(100) / \mathrm{Ti} / \mathrm{CoP}\left(800 \mathrm{mC} \mathrm{cm}^{-2}\right)$ electrode in $\mathrm{H}_{2}(\mathrm{~g})$-purged $0.50 \mathrm{M} \mathrm{H}_{2} \mathrm{SO}_{4}(\mathrm{aq})$. 


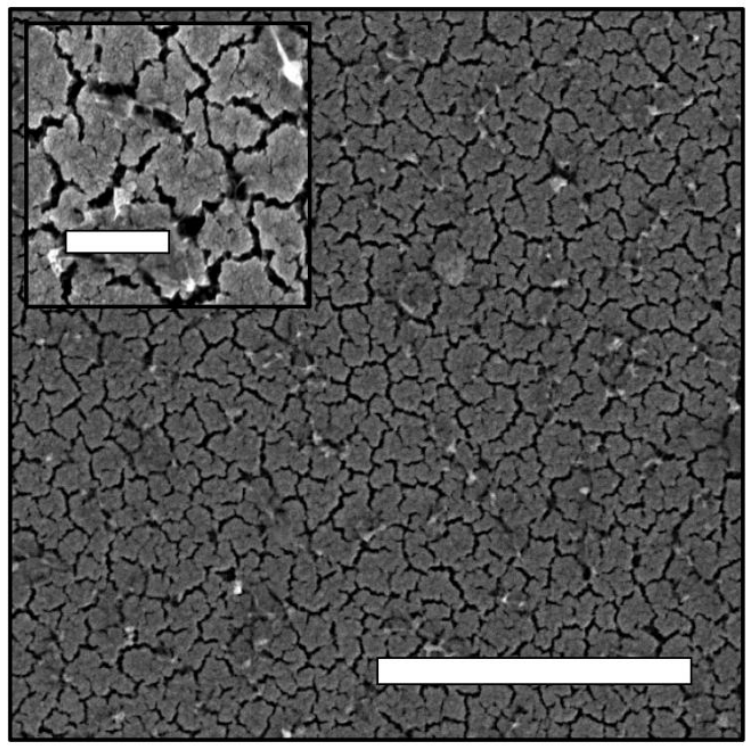

Figure S4: Top-down SEM image of an $\mathrm{n}^{+} \mathrm{p}-\mathrm{Si}(100) / \mathrm{Ti} / \mathrm{CoP}\left(400 \mathrm{mC} \mathrm{cm}^{-2}\right)$ photocathode after $15 \mathrm{~h}$ of continuous exposure to $0.50 \mathrm{M} \mathrm{H}_{2} \mathrm{SO}_{4}(\mathrm{aq})$. The scale bar in the primary image is $3 \mu \mathrm{m}$, and the inset scale bar is $500 \mathrm{~nm}$.

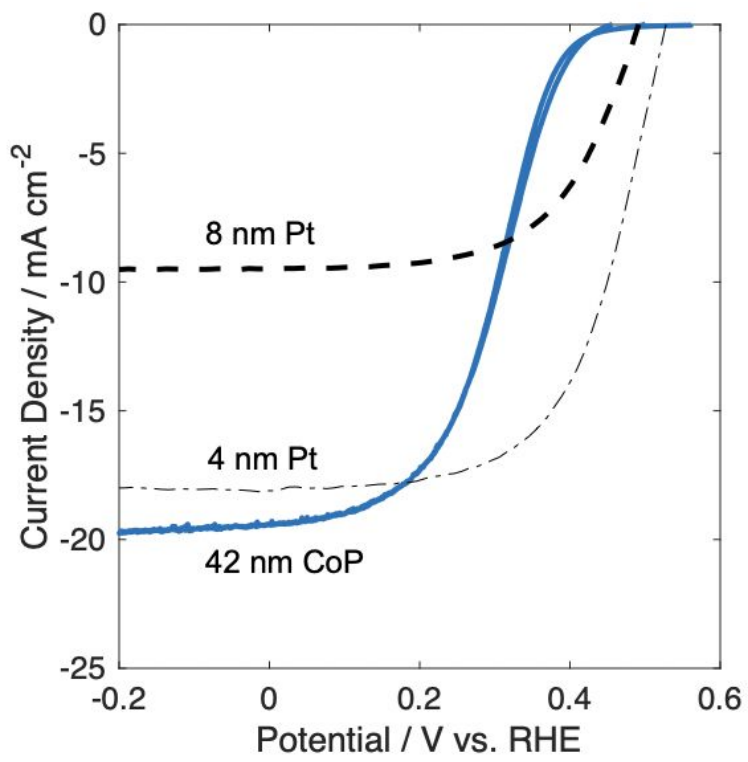

Figure S5: Comparison of the $J-E$ behavior for an $\mathrm{n}^{+} \mathrm{p}-\mathrm{Si}(100) / \mathrm{Ti} / \mathrm{Co} / \mathrm{CoP}\left(400 \mathrm{mC} \mathrm{cm}^{-2}\right)$ electrode under $100 \mathrm{~mW} \mathrm{~cm}^{-2}$ of simulated Air Mass 1.5 illumination in $0.50 \mathrm{M} \mathrm{H}_{2} \mathrm{SO}_{4}(\mathrm{aq})$ to nominally identical $\mathrm{n}^{+} \mathrm{p}-\mathrm{Si}(100)$ electrodes decorated with $4 \mathrm{~nm}$ and $8 \mathrm{~nm}$ of Pt. 


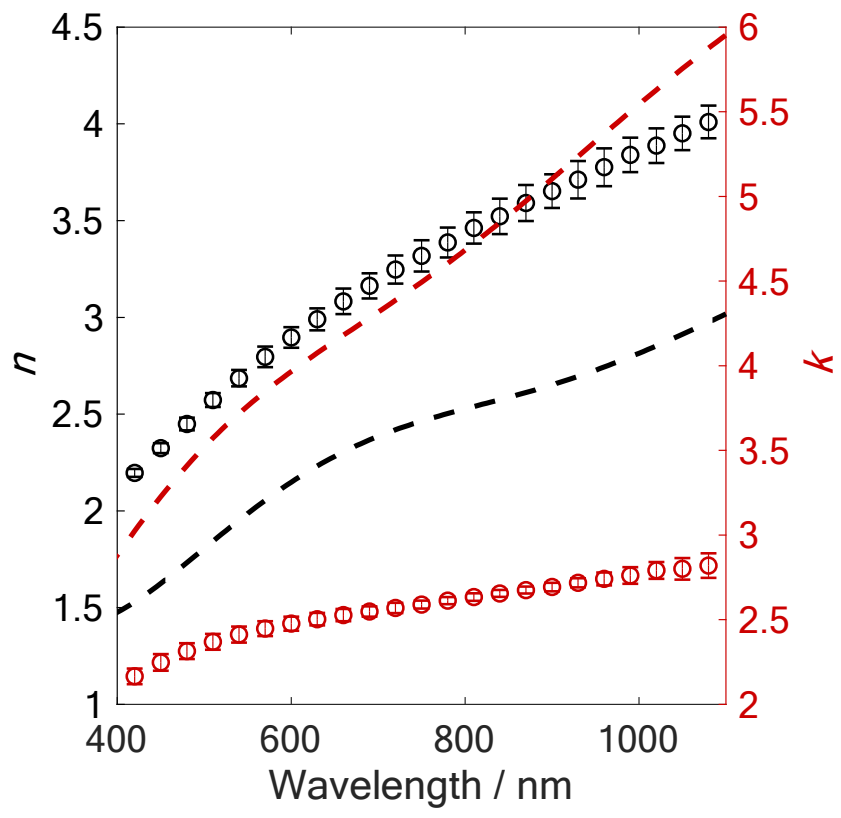

Figure S6: Real $(n)$ and imaginary $(k)$ components of the complex index of refraction, measured via spectroscopic ellipsometry in air, for as-deposited CoP films deposited to a thickness of $87 \pm$ $12 \mathrm{~nm}$, represented as open circles. Error bars represent one standard deviation between three independent samples. For comparison, $n$ and $k$ values for an $80 \mathrm{~nm}$ Co film are plotted as dashed lines. ${ }^{1}$
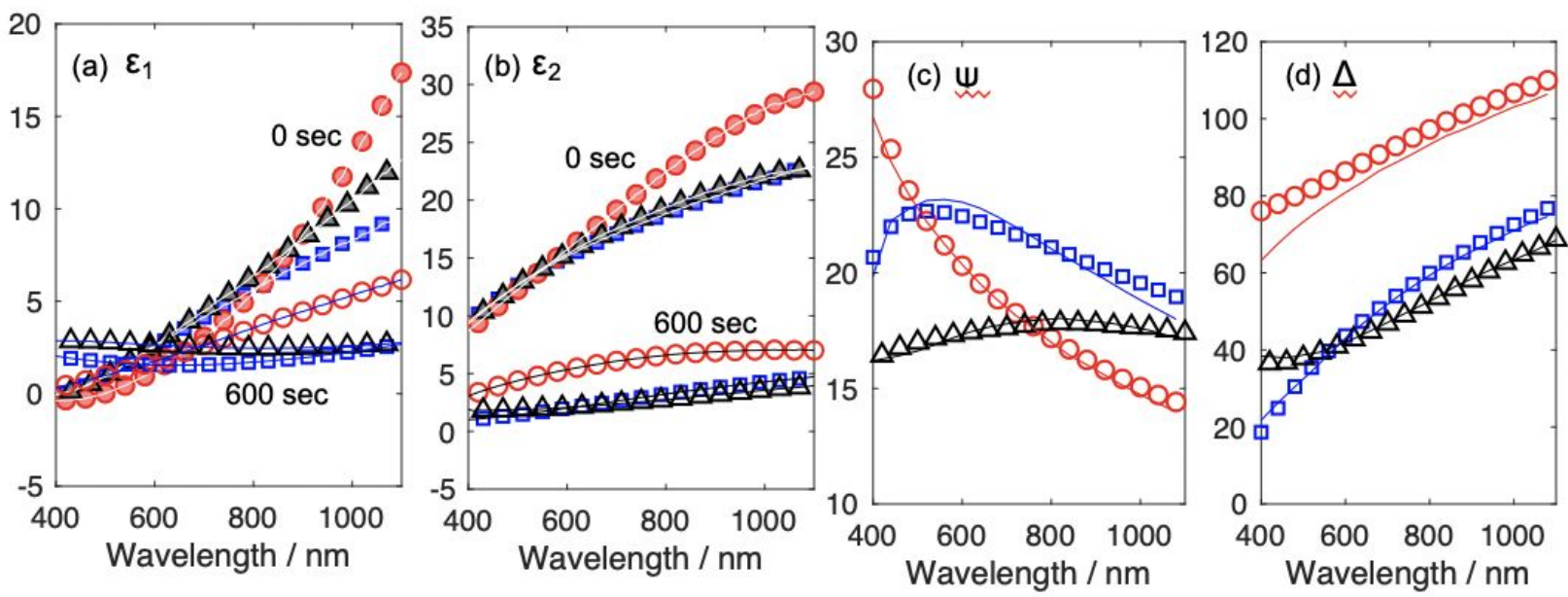

Figure S7: Spectroscopic ellipsometry of $\mathrm{n}^{+}-\mathrm{Si} / \mathrm{Ti} / \mathrm{Co} / \mathrm{CoP}$ samples at metal loadings of 400 (red circles), 800 (blue squares) and 1200 (black triangles) $\mathrm{mC} \mathrm{cm}^{-2}$. Measured data points are shown as individual markers, simulated data are represented as continuous lines (a) Real components and (b) Imaginary components of the dielectric functions of as deposited CoP films (filled markers) and films activated after 10 minutes of activation in $0.50 \mathrm{M} \mathrm{H}_{2} \mathrm{SO}_{4}$ (aq) (open markers). (c) Comparison of simulated and measured values for parameter Psi. (d) Comparison of simulated and measured values for parameter Delta. 


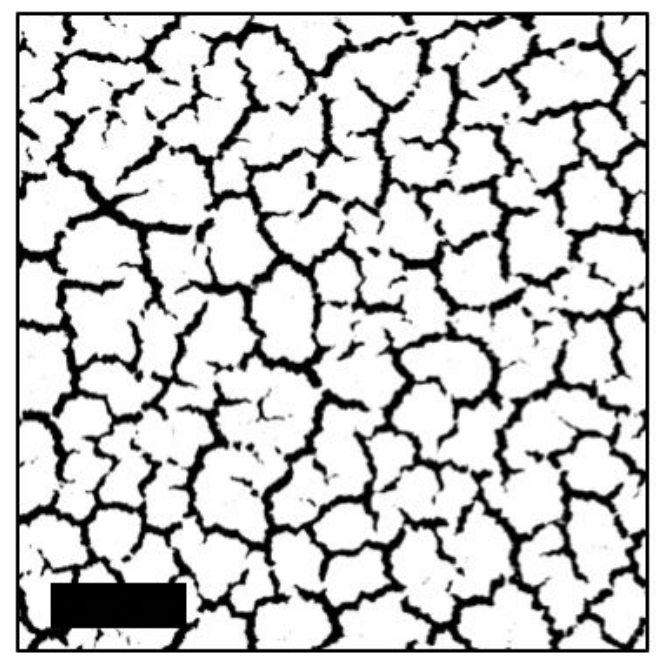

Figure S8: Binary SEM image of a $\mathrm{n}^{+}-\mathrm{Si}(100) / \mathrm{Ti} / \mathrm{CoP}\left(800 \mathrm{mC} \mathrm{cm}^{-2}\right)$ electrode after $10 \mathrm{~min}$ of $0.50 \mathrm{M} \mathrm{H}_{2} \mathrm{SO}_{4}(\mathrm{aq})$. The scale bar represents $500 \mathrm{~nm}$. The secondary electrons collected while imaging provided elemental contrast, where lighter regions were assigned to CoP and darker regions to bare $\mathrm{Si}$. The pixels were binned into catalyst and void regions so that the image could be used to estimate the void fraction.

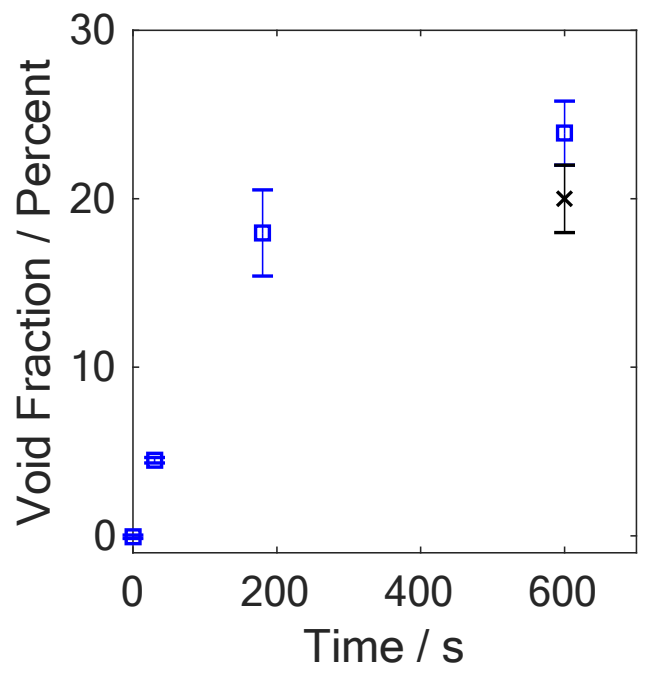

Figure S9: Change in void fraction as a function of time for $\mathrm{n}^{+}-\mathrm{Si}(100) / \mathrm{Ti} / \mathrm{CoP}\left(800 \mathrm{mC} \mathrm{cm}^{-2}\right)$ electrodes, as measured by ellipsometry (blue squares) in comparison to SEM measurements (black x). Error bars represent one-standard deviation across three independent samples.

\section{Estimation of corrosion rates:}

Assuming an average daily period of $12 \mathrm{~h}$ of dark, open-circuit conditions for the 10 years of operation, a constant corrosion rate while at open circuit, and a catalyst density of $6.5 \mathrm{~g} \mathrm{~cm}^{-3}$, a maximum rate of 0.2 picograms per second per $\mathrm{cm}^{2}$ of electrode area would be required. This rate of corrosion is approximately three orders of magnitude smaller than the rate of corrosion reported for studies on crystalline $\mathrm{Co}_{2} \mathrm{P}$ and $\mathrm{Ni}_{5} \mathrm{P}_{4} \cdot{ }^{2}$ 
Table S1: Performance comparison of photocathodes prepared from crystalline Si light absorbers coated with earth-abundant HER catalysts and tested under 1-Sun illumination in 0.50 $\mathrm{M} \mathrm{H}_{2} \mathrm{SO}_{4}(\mathrm{aq})$. In the absence of a reported average value, the potential at which a photocurrent density of $-10 \mathrm{~mA} \mathrm{~cm}^{-2}$ was obtained, $E_{10}$, was estimated from $J-E$ scan data. The short- circuit current density $J_{s c}$ measured at $0 \mathrm{~V}$ vs RHE serves as a proportional estimate of the collection efficiency of photons through the catalyst film when comparing substrates with equivalent reflectivities. Stability was assessed when available by chronoamperometry at $0 \mathrm{~V}$ vs RHE; the change in the photocurrent density during stability testing is expressed as a percentage, $\Delta J_{\mathrm{sc}}$, relative to the reported $J_{s c}$.

\begin{tabular}{|c|c|c|c|c|c|c|c|}
\hline Substrate & Catalyst & Thickness & $E_{10}[\mathrm{~V}$ vs RHE] & $J_{s c}\left[\mathrm{~mA} \mathrm{~cm}{ }^{-2}\right]$ & $\begin{array}{l}\text { Stability } \\
\text { (1 Sun) }\end{array}$ & $\Delta J_{s c}$ & Ref. \\
\hline $\mathrm{n}^{+} \mathrm{p}-\mathrm{Si}(100)$ & CoP Film & $40-50 \mathrm{~nm}$ & 0.318 & -19 & $12 \mathrm{~h}$ & $-9 \%$ & $\begin{array}{l}\text { This } \\
\text { work }\end{array}$ \\
\hline $\mathrm{n}^{+} \mathrm{p}-\mathrm{Si}(100)$ & CoP Islands & - & 0.230 & -15 & $12 \mathrm{~h}$ & $+13 \%$ & $\left({ }^{3}\right)$ \\
\hline $\mathrm{n}^{+} \mathrm{p}-\mathrm{Si}(100)$ & CoP Film & $5-7 \mathrm{~nm}$ & 0.345 & -19 & $24 \mathrm{~h}$ & $-3 \%$ & $\left({ }^{4}\right)$ \\
\hline $\mathrm{n}^{+} \mathrm{p}-\mathrm{Si}(100)$ & $\mathrm{MoS}_{2}$ Film & $3.6 \mathrm{~nm}$ & 0.190 & -17.1 & $100 \mathrm{~h}$ & $+10 \%$ & $(5)$ \\
\hline $\mathrm{n}^{+} \mathrm{p}-\mathrm{Si}(100)$ & $\mathrm{NiP}_{2}$ Film & $4-20 \mathrm{~nm}$ & 0.244 & -18 & $>120 \mathrm{~h}$ & $-9 \%$ & $\left({ }^{6}\right)$ \\
\hline $\mathrm{n}^{+} \mathrm{p}-\mathrm{Si}(100)$ & $\mathrm{MoS}_{2} / \mathrm{ZnO}$ & - & 0.307 & -21 & Not reported & - & $\left({ }^{7}\right)$ \\
\hline $\mathrm{p}-\mathrm{Si}(100)$ & $\mathrm{MoS}_{\mathrm{x}} \mathrm{Cl}_{\mathrm{y}}$ & $40-50 \mathrm{~nm}$ & 0.125 & -20.6 & Not reported & - & $\left({ }^{8}\right)$ \\
\hline $\mathrm{n}^{+} \mathrm{p}-\mathrm{Si} \mu \mathrm{P}$ & $\mathrm{MoSe}_{\mathrm{x}} \mathrm{Cl}_{\mathrm{y}}$ & - & 0.257 & -38 & $2 \mathrm{~h}$ & $-9 \%$ & $\left({ }^{8}\right)$ \\
\hline $\mathrm{n}^{+} \mathrm{p}-\mathrm{Si} \mu \mathrm{P}$ & $\mathrm{MoS}_{\mathrm{x}} \mathrm{Cl}_{\mathrm{y}}$ & - & 0.317 & -42 & $2 \mathrm{~h}$ & $-11 \%$ & $\left({ }^{8}\right)$ \\
\hline $\mathrm{n}^{+} \mathrm{p}-\mathrm{Si} \mu \mathrm{P}$ & CoPS & $10 \mathrm{~nm}$ & 0.334 & -26 & Not reported & - & $\left({ }^{9}\right)$ \\
\hline p-Si NW & $\mathrm{NiCoSe}$ & $60-70 \mathrm{~nm}$ & 0.150 & -40 & $2 \mathrm{~h}$ & $-9 \%$ & $\left({ }^{10}\right)$ \\
\hline $\mathrm{n}^{+} \mathrm{p}-\mathrm{Si} \mu \mathrm{W}$ & CoP Islands & - & 0.320 & -24 & $12 \mathrm{~h}$ & $-8 \%$ & $\left({ }^{3}\right)$ \\
\hline $\mathrm{n}^{+} \mathrm{p}-\mathrm{Si} \mu \mathrm{W}$ & NiMo & - & $0.390^{\mathrm{a})}$ & -35.5 & 72 hours, $\mathrm{pH} 4$ & - & $\left({ }^{11}\right)$ \\
\hline
\end{tabular}

a) Measurement in $0.10 \mathrm{M} \mathrm{H}_{2} \mathrm{SO}_{4}$. 


\section{References}

1. Palik, E. D., Handbook of Optical Constants of Solids. Academic press: 1998; Vol. 3.

2. Ledendecker, M.; Mondschein, J. S.; Kasian, O.; Geiger, S.; Göhl, D.; Schalenbach, M.; Zeradjanin, A.; Cherevko, S.; Schaak, R. E.; Mayrhofer, K., Stability and Activity of Non-Noble-Metal-Based Catalysts toward the Hydrogen Evolution Reaction. Angew. Chem. Int. Ed. 2017, 56 (33), 9767-9771.

3. Kempler, P. A.; Gonzalez, M. A.; Papadantonakis, K. M.; Lewis, N. S., Hydrogen Evolution with Minimal Parasitic Light Absorption by Dense Co-P Catalyst Films on Structured P-Si Photocathodes. ACS Energy Lett. 2018, 3 (3), 612-617.

4. Hellstern, T. R.; Benck, J. D.; Kibsgaard, J.; Hahn, C.; Jaramillo, T. F., Engineering Cobalt Phosphide (Cop) Thin Film Catalysts for Enhanced Hydrogen Evolution Activity on Silicon Photocathodes. Adv. Energy Mat. 2016, 6 (4).

5. $\quad$ Benck, J. D.; Lee, S. C.; Fong, K. D.; Kibsgaard, J.; Sinclair, R.; Jaramillo, T. F., Designing Active and Stable Silicon Photocathodes for Solar Hydrogen Production Using Molybdenum Sulfide Nanomaterials. Adv. Energy Mat. 2014, 4 (18), 1400739.

6. Hwang, S.; Porter, S. H.; Laursen, A. B.; Yang, H.; Li, M.; Manichev, V.; Calvinho, K. U.; Amarasinghe, V.; Greenblatt, M.; Garfunkel, E., Creating Stable Interfaces between Reactive Materials: Titanium Nitride Protects Photoabsorber-Catalyst Interface in Water-Splitting Photocathodes. J. Mat. Chem. A 2019, 7 (5), 2400-2411.

7. Hellstern, T. R.; Nielander, A. C.; Chakthranont, P.; King, L. A.; Willis, J. J.; Xu, S.; Maclsaac, C.; Hahn, C.; Bent, S. F.; Prinz, F. B., Nanostructuring Strategies to Increase the Photoelectrochemical Water Splitting Activity of Silicon Photocathodes. ACS Applied Nano Materials 2019, 2 (1), 6-11.

8. Ding, Q.; Zhai, J.; Cabán-Acevedo, M.; Shearer, M. J.; Li, L.; Chang, H. C.; Tsai, M. L.; Ma, D.; Zhang, X.; Hamers, R. J., Designing Efficient Solar-Driven Hydrogen Evolution Photocathodes Using Semitransparent Moqxcly $(\mathrm{Q}=\mathrm{S}$, Se) Catalysts on Si Micropyramids. Adv. Mater. 2015, 27 (41), 6511-6518.

9. Cabán-Acevedo, M.; Stone, M. L.; Schmidt, J. R.; Thomas, J. G.; Ding, Q.; Chang, H.-C.; Tsai, M.-L.; He, J.-H.; Jin, S., Efficient Hydrogen Evolution Catalysis Using Ternary Pyrite-Type Cobalt Phosphosulphide. Nat. Mat. 2015, 14, 1245.

10. Zhang, H.; Ding, Q.; He, D.; Liu, H.; Liu, W.; Li, Z.; Yang, B.; Zhang, X.; Lei, L.; Jin, S., A P$\mathrm{Si} /$ Nicosex Core/Shell Nanopillar Array Photocathode for Enhanced Photoelectrochemical Hydrogen Production. Energy Environ. Sci. 2016, 9 (10), 3113-3119.

11. Vijselaar, W.; Westerik, P.; Veerbeek, J.; Tiggelaar, R. M.; Berenschot, E.; Tas, N. R.; Gardeniers, H.; Huskens, J., Spatial Decoupling of Light Absorption and Catalytic Activity of NiMo-Loaded High-Aspect-Ratio Silicon Microwire Photocathodes. Nat. Energy 2018, 3 (3), 185192. 